\title{
AN EARLY SUMMER'S BIRDING AT CHURCHILL, MANITOBA
}

RUDOLF F. KOES, 135 Rossmere Crescent, Winnipeg, MB R2K 0G1

A visit to Churchill, on the southwestern edge of Hudson Bay, is high on the wish list of many birders throughout North America. The town and its surroundings allow the easiest access to the near-Arctic anywhere in North America and numerous bird species rarely seen in the south can be observed here in numbers and at close range. From early June to mid-July, the area teems with migrants and breeding birds; consequently, this is the time of year when most birding tours occur. Visiting later in the year may also be rewarding, particularly in late fall, but daily tallies will be lower and some of the most sought-after species will be harder to find or may be absent.

Spring normally starts in earnest in early June, with the break up of ice in the mouth of the Churchill River and on the bay, but the spring of 1999 was exceptionally early. Apparently the bay ice had only been $4-5$ feet $(1.2-1.5 \mathrm{~m}$ ) thick, as compared to the usual 8 feet $(2.4 \mathrm{~m})$, and May weather had been more like what one would expect in June. How advanced the season was became clear as I approached Churchill from the air on June 3. As the plane banked for its landing, Hudson Bay stretched to the north, uniform blue, with a few scattered icebergs on the horizon. Below, the tundra was brown - not a trace of snow. On the ground Purple Saxifrage (Saxifraga oppositifolia) had already finished blooming, Mountain Avens (Dryas integrefolia) were in full flower, and Alpine Milk Vetch (Astragalus alpinus) and Northern Hedysarum (Hedysarum mackenzil) were well underway. At this time of year, open water is usually scarce and the mouth of the Churchill River often harbours hundreds of loons and ducks. The town dump normally hosts numerous gulls. But they were gone, lured to the north by the balmy weather.

The exceptional conditions resulted in one of the strangest seasons on record. While hoped-for northern migrants, such as Red Phalarope and Sabine's Gull, never appeared, a host of "southern" birds more than made up for their absence. Between June 3 and 18, the two birding groups I led recorded 137 species (Table 1), many of them very rare locally. A few of the highlights are worth mentioning here. Pomarine Jaegers appeared briefly in mid-month. Some of us were treated to a flyby on the $15^{\text {th }}$, while all had good looks at an adult circling over Cape Merry on the $17^{\text {th }}$. This was a "lifer" for most! Rare larids seen included Mew Gull and Little Gull. Unfortunately, we missed the Ross's Gull spotted by a lucky few of the other visitors. This mythical bird has been present annually in Churchill since 1980, but numbers have dwindled in the past few years and its future in the region is uncertain. A Hairy Woodpecker in the Twin Lakes burn on 11 June was the first for the Churchill area since a possible record prior to 1845 ! This was a male bird; amazingly, a female was noted about a week later. Also very unexpected were Olive-sided Flycatcher and Eastern Kingbird, both new on my Churchill list. A very elusive Black-billed Magpie, so ho-hum on the prairies, finally revealed itself after our many days of searching. It seemed that everybody else had seen it, except for us. The final highlight was a Rock Wren, which was found and videotaped by a group of Swedish birders during their lunch break on the rocks along the coast. This little sprite became a star attraction for all the birding groups during the week after its discovery. Thrice before had this species been found in Churchill; twice it had even attempted to nest.

Besides birds, there are many other natural attractions. Beluga Whales frequent the mouth of the river, increasing in numbers as the summer progresses, and Harbour and Bearded Seals can often be seen hauled out on the rocks in the river or on a chunk of ice in the bay. The occasional Caribou is sighted and Polar Bears may come off the bay ice at this time of year, but both species are relatively rare in spring and summer. Still, birders should exercise care when 
clambering over rocks or hiking along forest trails. For the botany buffs, the profusion of wildflowers will be a delight. Insects are the scourge of the north country and, in this respect, Churchill is no different. While early groups sometimes arrive before the mosquitoes and black flies do, most visitors will not be able to escape the bugs on warm and calm days. If you plan to visit, arm yourself with DEET or a bug jacket, or live with the consequences.

A visit of five days to a week is adequate to check all local hot spots a number of times and to find most of the species present. A trip list of about 100 species can be expected. Favorite haunts of the birding crowd are Cape
Merry, at the mouth of the river, Akudlik Marsh, between the town site and the airport, Goose Creek and Hydro Roads, and the Twin Lakes area. Detailed information on these sites and others is provided in A Birder's Guide to Churchill, written by local expert Bonnie Chartier, and published by the American Birding Association. This guide also has useful information on transportation, accommodation and the historic sites around town. Don't leave home without it!

The summer of 1999 proved to be out-ofthe-ordinary, but then, that is the lure of Churchill. Expect the unexpected. Put the town on your list of places to visit and you will not be disappointed.

\section{Table 1. Bird species observed by Churchill Northern Studies Centre birding groups between 3 and 18 June 1999.}

\begin{tabular}{|c|c|c|}
\hline Red-throated Loon & American Golden-Plover & Common Raven \\
\hline Pacific Loon & Semipalmated Plover & Horned Lark \\
\hline Common Loon & Killdeer & Tree Swallow \\
\hline Horned Grebe & Greater Yellowlegs & Barn Swallow \\
\hline American Bittern & Lesser Yellowlegs & Boreal Chickadee \\
\hline Snow Goose & Solitary Sandpiper & Brown Creeper \\
\hline Ross's Goose & Spotted Sandpiper & Rock Wren \\
\hline Canada Goose & Whimbrel & Winter Wren \\
\hline Tundra Swan & Hudsonian Godwit & Ruby-crowned Kinglet \\
\hline Gadwall & Ruddy Turnstone & Gray-cheeked Thrush \\
\hline American Wigeon & Sanderling & Hermit Thrush \\
\hline American Black Duck & Semipalmated Sandpiper & American Robin \\
\hline Mallard & Least Sandpiper & European Starling \\
\hline Blue-winged Teal & White-rumped Sandpiper & American Pipit \\
\hline Northern Shoveler & Dunlin & Bohemian Waxwing \\
\hline Northern Pintail & Stilt Sandpiper & Tennessee Warbler \\
\hline Green-winged Teal & Short-billed Dowitcher & Orange-crowned Warbler \\
\hline Canvasback & Common Snipe & Nashville Warbler \\
\hline
\end{tabular}




\begin{tabular}{|c|c|c|}
\hline Redhead & Wilson's Phalarope & Yellow Warbler \\
\hline Ring-necked Duck & Red-necked Phalarope & Yellow-rumped Warbler \\
\hline Greater Scaup & Pomarine Jaeger & Palm Warbler \\
\hline Lesser Scaup & Parasitic Jaeger & Blackpoll Warbler \\
\hline Common Eider & Long-tailed Jaeger & Northern Waterthrush \\
\hline Surf Scoter & Little Gull & American Tree Sparrow \\
\hline White-winged Scoter & Bonaparte's Gull & Chipping Sparrow \\
\hline Black Scoter & Mew Gull & Clay-colored Sparrow \\
\hline Oldsquaw & Ring-billed Gull & Savannah Sparrow \\
\hline Bufflehead & Herring Gull & Le Conte's Sparrow \\
\hline Common Goldeneye & Thayer's Gull & $\begin{array}{l}\text { Nelson's Sharp-tailed } \\
\text { Sparrow }\end{array}$ \\
\hline Hooded Merganser & Glaucous Gull & Fox Sparrow \\
\hline Common Merganser & Common Tern & Song Sparrow \\
\hline Red-breasted Merganser & Arctic Tern & Lincoln's Sparrow \\
\hline Osprey & Black Guillemot & Swamp Sparrow \\
\hline Bald Eagle & Snowy Owl & White-throated Sparrow \\
\hline Northern Harrier & Short-eared Owl & Harris's Sparrow \\
\hline Red-tailed Hawk & Hairy Woodpecker & White-crowned Sparrow \\
\hline Rough-legged Hawk & Three-toed Woodpecker & Dark-eyed Junco \\
\hline American Kestrel & Black-backed Woodpecker & Lapland Longspur \\
\hline Merlin & Northern Flicker & Smith's Longspur \\
\hline Peregrine Falcon & Olive-sided Flycatcher & Snow Bunting \\
\hline Spruce Grouse & Alder Flycatcher & Rusty Blackbird \\
\hline Willow Ptarmigan & Eastern Kingbird & Pine Grosbeak \\
\hline Sora & Northern Shrike & Common Redpoll \\
\hline American Coot & Gray Jay & Hoary Redpoll \\
\hline Sandhill Crane & Black-billed Magpie & House Sparrow \\
\hline Black-bellied Plover & an Crow & \\
\hline
\end{tabular}




\section{Acknowledgements}

Many thanks go to the participants in the two birding courses offered in 1999 by the Churchill Northern Studies Centre: Liesel and Reinhard Jansson, Susan Loeppky, Robert Parsons and Renee and Tom Will in the first group, and Gord and Susan Grieef, Maxine
Reid, Millie Reid, Margaret Yorke and Reto Zach during the second week. Their enthusiasm and sharp eyes made the visit memorable. Also, a vote of thanks to the staff of the Centre, which worked hard to make things run as smoothly as possible. Finally, as always, Peter Taylor had many helpful suggestions, which improved the manuscript.

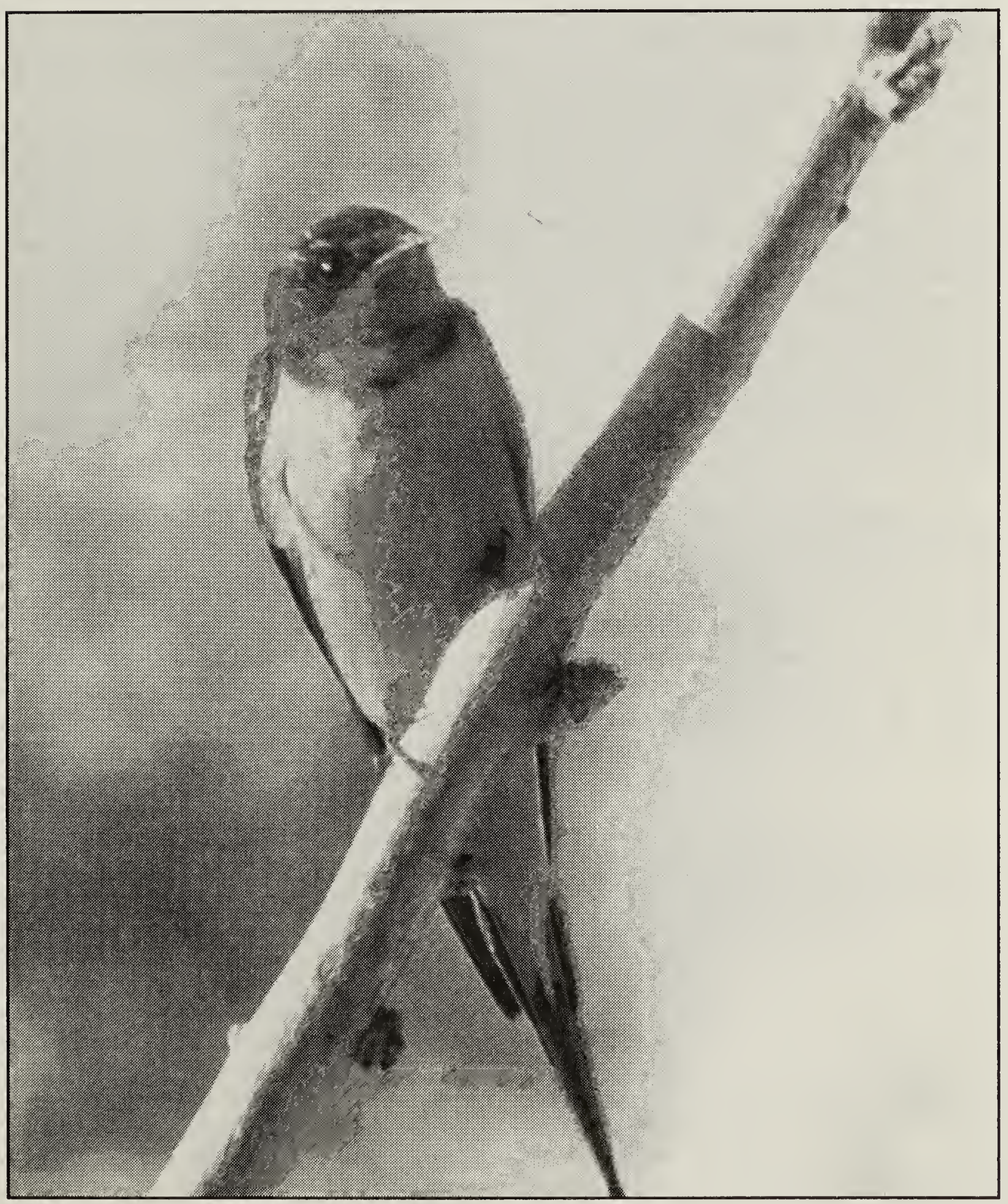

